\title{
Five brave pagan women in the work of Tertullian
}

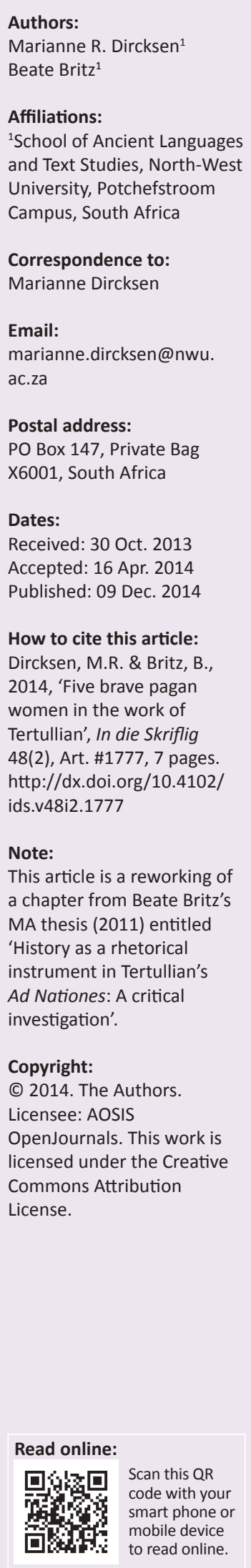

Historical exempla have been employed as a rhetorical stratagem since the 8th century BCE. The Christian apologist Tertullian, who received thorough training in rhetoric, was familiar with this device. Lucretia, Cleopatra, Dido, 'the wife of Hasdrubal' and Leaena also appear in the works of Roman authors as typical examples of bravery. In his Ad Martyres (4), Tertullian groups together all five as fine examples of bravery when facing death. Four of the examples appear in his Ad Nationes (1.18) and two in the Liber Apologeticus (50). Both the Ad Nationes and the Liber Apologeticus were written in defence of the Christians. In Tertullian's De exhortatione castitatis (13.3) and the De Monogamia (17), Lucretia and Dido are referred to as exempla of chastity and monogamy. The first four paragraphs preceding the analysis of these texts provide the context and contain background information on the Christian apologists, a short biography of Tertullian, a few remarks on the use of history as a rhetorical tool and a discussion on the place of these women in ancient pagan literature. The investigation of Tertullian's use of the exempla to bolster his argument reveals how he adapted these stock examples of pagan women to fit the Christian context, and illustrates how and why ancient rhetoric became part of Christian literary tradition.

Vyf dapper heidense vroue in die werk van Tertullianus. Historiese exempla word al sedert die agtste eeu v.C. as 'n retoriese strategie benut. Die Christen apologeet, Tertullianus, wat 'n grondige opleiding in retoriek ontvang het, was vertroud met hierdie tegniek. Lucretia, Cleopatra, Dido, 'Hasdrubal se vrou' en Leaena kom ook in die werke van Romeinse outeurs voor as tipiese voorbeelde van dapperheid. In sy Ad Martyres (4) groepeer Tertullianus al vyf saam as goeie voorbeelde van dapperheid in die aangesig van die dood. Vier van die voorbeelde kom in die Ad Nationes (1.18) voor en twee in sy Liber Apologeticus (50). Albei hierdie werke is geskryf om die Christene te verdedig. In Tertullianus se De exhortatione castitatis (13.3) en die De Monogamia (17) word na Lucretia en Dido as voorbeelde van kuisheid en monogamie verwys. Die eerste vier paragrawe wat die analise voorafgaan, gee die konteks en bevat agtergrondinligting oor die Christen apologete, 'n kort biografie van Tertullianus, 'n paar opmerkings oor die gebruik van geskiedenis as retoriese instrument en 'n bespreking van die plek van die vyf vroue in antieke heidense letterkunde. Die ondersoek na Tertullianus se gebruik van hierdie exempla om sy argument te versterk, dui aan dat hy die standaardvoorbeelde van heidense vroue aangepas het om by die Christelike konteks te pas, en illustreer hoe en waarom antieke retoriek deel van die Christelike literêre tradisie geword het.

\section{The Christian apologists}

Since the Roman authorities initially regarded the Christians as a Jewish group (Wedderburn 2004:186), Christians benefitted from the Roman tolerance of Judaism (Clark 2004:6). Moreover, the Romans made no attempt to establish a universal cult or belief system in the Roman Empire nor did they suppress any cult, unless Roman religious feeling was offended or public order endangered (Clark 2004:5). However, after the Jewish revolt in 66 CE, the Christians were perceived as a separate religious sect. As an entity with a unique identity, they were viewed with suspicion since their monotheistic exclusiveness was thought to anger the gods, to endanger the pax deorum ${ }^{1}$ and to be the cause of disasters (De Ste. Croix 1963:24). The Apologists, who were learned leaders and theologians, spearheaded the defence of Christians against this suspicion and persecution. Norris (2004) describes the Apologists as

\footnotetext{
... authors who enjoyed a fuller education in the Greek manner than the majority of Christians, who could therefore envisage and present their faith in a way that might make it appear comprehensible and tolerable, if not attractive, to initially hostile readers. (pp. 36-37)
}

Their education incorporated a thorough grounding in classical rhetoric, philosophy and pagan literature - influences that are evident in their works. 
The Christian apologists did not invent a unique genre, since Hellenised Jewish ${ }^{2}$ authors, earlier Christian authors ${ }^{3}$ as well as writers from the Graeco-Roman world, ${ }^{4}$ already produced works that were apologetic in nature. The structure of argumentation the Apologists used, was therefore underpinned by established and well-known generic conventions, which ideally suited their purpose of defending the Christians.

\section{Tertullian}

One of the apologists was Quintus Septimius Florens Tertullianus or Tertullian, as he is known in the Englishspeaking world. Since Tertullian is the earliest Christian author who wrote in Latin and whose works are extant, he is an important figure in Christian literature. ${ }^{5}$ Barnes (1971) established what is currently held to be the most reliable biography of Tertullian. ${ }^{6}$ Basing his calculations on Tertullian's own testimony, he proposes that Tertullian was born c. 170 in Carthage in Roman Africa (Barnes 1971:58). Barnes discredits the widely held assumptions that Tertullian's father was a centurion and that he himself was a jurisconsult or became a priest. The date of his conversion from paganism to Christianity and subsequent marriage to a Christian wife is uncertain, but we know that he belonged to the literary circles and intellectual culture of Carthage during the reign of Septimius Severus and his son Caracalla (Barnes 1971:57-59). Carthage was undoubtedly the intellectual centre of the African provinces (Barnes 1971:187-210). Barnes convincingly argues that Tertullian was well-read in both the classical authors and those of silver Latinity (Barnes 1971:192-206) and that he was familiar with the precepts of rhetorical theory (pp. 206-210; also see Dunn 2004:5; Sider 1971:126-132). Preferring the austere doctrines and practices of Montanus to Catholicism, he became a Montanist and subsequently the head of the Montanist party in Africa a party that existed until the 5th century under the name Tertullianists. He wrote all his extant treatises over a relatively short period, from 196 to 212 CE. Barnes estimates that he possibly died in middle age, perhaps as a martyr whom the Church preferred to forget, but the date and circumstances of his death remain blurred (Barnes 1971:59).

\section{The historical example as rhetorical tool}

Textbooks containing lists of examples pertaining to each of the different kinds of virtue had been compiled for the convenience of orators and for use in philosophical and

2.Philo's Defence on behalf of the Jews, and Josephus's Ad Apionem.

3.Richard Norris (2004:36) notes that some biblical passages contain instances of discourse that pursue apologetic aims and methods, for example Paul's speech in Acts 17:22 ff.

4.Plato's Apology and Apuleius's Apology.

5.In the title of his study, Eric Osborn (1997), refers to Tertullian as 'The first theologian of the west'.

6.The chronology proposed by Barnes, is now generally accepted (see e.g. DanielHughes 2011:121; Wilhite 2007:17 and the review of Sider 1974). The short biography above is largely based on Barnes' findings. moral treatises long before the time of the Christian authors (Carlson 1948:93). Rhetoric distinguishes three kinds of examples: examples from everyday life, examples from history and the poetical example. Of these three, the historical example is most frequently used since it provides a proven and well-known effect that increases its power of persuasion (Ueding 1996:71-72).

All ancient rhetoricians knew and appreciated the value of the historical example. Aristotle (Rhet. 1.9.40; 2.20.8) stated that historical examples are most suitable since we predict the future from the past, and Seneca (Ep. Mor. 1.6.5) explains why examples are such an effective rhetorical device when he says: 'Longum iter est per praecepta, breve et efficax per exempla' ['The journey by way of precepts is long, but short and efficient through examples']. Both Cicero (Top. 44) ${ }^{7}$ and Quintilian (Inst. 5.11) independently attest to the efficacy of examples from history in the art of oratory. The great Roman rhetorician, Quintilian, explains why history is such a valuable tool in arguing a case:

Est et alius ex historiis usus, et is quidem maximus sed non ad praesentem pertinens locum, ex cognitione rerum exemplorumque, quibus in primis instructus esse debet orator; nec omnia testimonia expectet a litigatore, sed pleraque ex vetustate diligenter sibi cognita sumat, hoc potentiora quod ea sola criminibus odii et gratia vacant. [Another important and valuable advantage to be gained from history, though irrelevant for the present discussion, is the author's own thorough knowledge of historical facts and examples. This would enable him to prove his case by utilising his accurate knowledge of history and not being totally reliant on his client for all evidence. Such arguments are all the more persuasive, as they alone are exempt from the charges of prejudice and partiality.] (Inst. 10.1.34, [author's own translation])

Africa was well-known for its schools of rhetoric. Our sources attest to the fact that the study and practice of eloquence was met with even greater encouragement in this province than in Rome (Woodham 1848:xii), and Tertullian undoubtedly had more than a passing knowledge of its technicalities. The church fathers knew that it would be advantageous to refute their pagan opponents with their own arguments and their own examples. These methods of persuasion can in many cases be traced directly to their rhetorical training (Carlson 1948:93-94). The examples of the Roman rhetoricians were familiar to the church fathers and to a large part of their audience. Apart from Cyprian and Ambrose, who both avoided pagan examples (Carlson 1948:94) and opted for references to Scripture only, the works of the Christian fathers contained many examples taken from Greek and Roman history. The argument behind the use of pagan examples to motivate Christians is clear (Carlson 1948):

If certain pagans were acknowledged to be courageous, surely the Christians, by being reminded of these models of fortitude, could be spurred on with hopes of eternal reward to emulate and surpass their feats. (p. 96)

7.D’Arms (1972) illustrates Cicero's skilful employment of the careers of Pompeius and Scaurus as historical exempla in rhetoric. 
The Christian idea of a free spirit that survives the physical body (1 Cor 15:35-55) was not foreign to the Romans. The Roman Stoic philosopher, Seneca (Ep. 65.21), argued that although one's body can be in peril of injury or slavery, the soul remains whole and free. Tertullian's examples of bravery taken from the pagan past therefore resonated with Christian thought.

\section{References to the exempla of pagan woman in classical literature}

In his discussions concerning the use of examples, Quintilian (Inst. 5.11.10) believed that courage is more deserving of admiration in a woman than in a man. Tertullian adhered to this prescript and used examples of five brave pagan women to encourage, admonish and defend the Christians. These five women are Lucretia, Dido, 'the wife of Hasdrubal' (her name is not mentioned by any of the sources), Cleopatra and Leaena. The clustering of these names in the Ad Martyras and also in the Ad Nationes (with the exception of Lucretia) is a clear indication that they belonged to collections or lists of examples used in a classical rhetorical education. There were indeed whole works devoted to catalogues of women, such as the Eoiae attributed to Hesiod. Orators and authors could select examples from categories that suited their rhetorical purpose. In the following paragraph, the depiction of these five women in pagan literature is examined to determine in which context and for what purpose their examples were utilised.

\section{Lucretia}

Lucretia's story is told in Livy 1.57-58, and this version was most probably known to Tertullian and his audience. After being raped by the son of the Etruscan king, Tarquinius Superbus, she committed suicide by plunging a knife into her heart. The incident led to the overthrow of the last king of Rome and the institution of the republic. Her husband, Lucius Tarquinius Collatinus, was one of the first two republican consuls. Livy's account (1.58), and especially Lucretia's final words, were famous: 'ego me etsi peccato absolvo, supplicio non libero; nec ulla deinde impudica Lucretiae exemplo vivet' ['Although I absolve myself from the sin, I do not free myself from the penalty; no unchaste woman shall henceforth live according to Lucretia's example.']. Her suicide was firmly entrenched in the rhetorical tradition and, as a subject for declamation, in the schools. Classical authors used her example to illustrate both chastity and courage. Valerius Maximus, who composed a handbook of illustrative examples for rhetoricians, described Lucretia as dux Romanae pudicitiae [the foremost (example) of Roman chastity] (Val. Max. 6.1.1), whilst Quintilian (Inst. 5.11.10) valued her example of fortitude in the face of death (ad moriendum) above that of Cato and Scipio. ${ }^{8}$

\section{Dido and 'the wife of Hasdrubal'}

Undoubtedly the heroines of Carthage appealed to Tertullian since he was from Africa himself, and just as Christian women died burning at the stakes, Dido and 'the wife of Hasdrubal' were also both examples of women who died by fire. In the case of Dido, he does not follow the Virgilian and Ovidian version of the narrative where she is portrayed as a desperate and humiliated woman spurned by Aeneas, ${ }^{9}$ but prefers an earlier account by the Greek historian, Timaeus (Lord 1969:32). Jerome (Adv. Iovinian. 1.43) supplies the following detail: After sailing to Africa from Tyre and founding the city of Carthage, Dido's hand was sought in marriage by Iarbas, king of Lybia. She put off the nuptials in order to establish her city. Not long after, however, she erected a pyre to her former husband, Sychaeus, and then sacrificed herself in order to avoid marrying Iarbas and stay true to her first husband. ${ }^{10}$ Justin (Epit. of Pompeius Trogus 18.4-6) tells us that when Dido ascended the pyre, she killed herself with a sword, but Tertullian and most other Christian authors purposefully emphasise Dido's death by fire.

There are also three extant earlier versions concerning the 'wife of Hasdrubal'. Valerius Maximus (3.2.ext.8) relates how, after the capture of Carthage, she reproached her husband for his disloyalty in surrendering to Scipio - and grabbing her sons in her right and left hand, she jumped into the flames of the burning city. Florus' version (1.31.17) is very similar, but he adds that in hurling herself from the roof of her house into the flames, she was following the example of the queen who founded Carthage (Dido). The version less consonant with her role as an example of fortitude is from Livy (Perioch. 51). According to him, Hasdrubal's wife had unsuccessfully tried to persuade her husband a few days earlier to surrender to the conqueror (ut ad victorem transfugerent) and then threw herself from the citadel into the inferno of the burning city.

Since Tertullian's successors also quote these two examples in the same context, it seems as if they made use of the same collection of examples. In Epistula 12.3 Jerome connects the examples of Dido and 'the wife of Hasdrubal', and in Adversus Iovinianum 1.43 he uses Carthage as the link between the stories of Dido and the wife of Hasdrubal. The chaste Dido founded Carthage, and when it was being demolished by fire many years later, another chaste woman, the wife of Hasdrubal, took her children by the hand and jumped into the flames of the city to avoid capture by the Romans.

\section{Cleopatra}

Cleopatra's death was a favourite subject amongst ancient authors, resulting in various different versions. The traditional story of Cleopatra's death as given by Plutarch

9.In the fourth book of the Aeneid, Virgil tells how Dido fled from her home in Tyre after her rich husband, Sychaeus, had been killed by her brother Pygmalion, king of Tyre. She becomes the founder of Carthage after cunningly bargaining for land with the Lybian king, larbas. When the Trojan, Aeneas, lands in Africa with his followers, Dido and Aeneas fall in love - much to the chagrin of larbas whose advances Dido had scorned. Aeneas is warned by the gods to leave for Italy and a heartbroken Dido ascends a pyre and falls on her sword. When feneas and a heartbroken Dido ascends a pyre and falls on her sword. When Aeneas and his crew see Dido's burning funeral pyre, they can only guess what happened. Edgeworth (1977) argues that the inclusion of the pyre as part of Dido's suicide was a later addition and can be ascribed to the self-immolation of the last queen
of Carthage in 146 BCE.

10.For a more detailed discussion of the two versions of Dido's death, see Lord (1969:39-40). 
(Ant. 86), Dio (51.14) and Strabo (17.1.10) is untrustworthy and was perhaps contaminated by contemporary politics and romanticisation (Cary \& Scullard 1994:626). According to these versions, she was either bitten by an asp or poisoned herself. Plutarch mentions that Augustus seemed to have believed that she was killed by a snake, since the statue of her in his triumphal procession featured a snake. It is probable that Cleopatra chose to die by the bite of an asp since the Egyptians believed that the snake was the divine minister of the Sun god - its victim was therefore deified. Cleopatra was not portrayed as a romantic heroine in classical literature. The ancient reference is perhaps Horace who, similar to Tertullian, admired the way she chose to die, although he condemns the way she lived:
Ausa et iacentem visere regiam
Vultu sereno, fortis et asperas
Tractare serpentis, ut atrum
Corpore combiberet venenum ...
[She dared, with calm expression
to see her kingdom lying there
and bravely she handled the fierce snakes
so that she may absorb into her body the deadly venom ...]
(Carm 1.37, [author's own translation])

\section{Leaena}

The fifth example of a pagan woman who features in Tertullian's work is that of the Athenian hetaera [courtesan or mistress], Leaena. She was suspected of being engaged in the plot of Harmodius and Aristogeiton to kill Hipparchus, the son of Pesistratos. When tortured by Hippias, she bit off and spat out her tongue in the face of the torturer so that she would not be able to betray the traitors. The story is told by Plutarch (De Garr. 8) and he adds that, as a monument to her virtue, the Athenians set up a lioness (which is the meaning of the name Leaena) without a tongue in brass, at the entrance to the Acropolis (see also Ath. Deipnosophistae 13.70). The Elder Pliny (H.N. 7.23) also refers to Leaena, or meretrix Atheniensis [Athenian harlot], as an example of exceptional physical endurance (patientia corporis).

\section{Exempla of pagan women}

The following analysis illustrates Tertullian's adaptation of these exempla to fit his own purpose - whether this purpose was the encouragement of Christian women awaiting death, the defence of Christians, or portraying them as examples of monogamy and chastity.

\section{To encourage Christian women facing death}

Tertullian adapted the traditional role of the women, as described above, to fit in with both Christian doctrine and the context and purpose of the specific treatise in which their examples are used.

All five these women are mentioned in the Ad Martyras. Tertullian's main purpose with his Ad Martyras is to encourage the Christian women awaiting torture and death in the prison of Carthage. In chapter 4.3, he tries to fortify their spirits against betrayal by the flesh. He cites instances of pagans who faced death unflinchingly (aequo animo) for the sake of fame and glory (famae et gloriae causa), stressing the fact that these pagans were not only men, but also women whose example should encourage them to match their own sex. Tertullian (Ad Martyras 4.3) addresses the Christian women as benedictae [blessed women] and then continues:

[4] Longum est, si enumerem singulos, qui se gladio confecerint, animo suo ducti. De feminis ad manum est Lucretia, quae vim stupri passa cultrum sibi adegit in conspectu propinquorum, ut gloriam castitati suae pareret. [It is a long tale, if I were to name each of those who, led by their own spirit, have slain themselves with the sword. Of women, Lucretia is a ready example, who having suffered violation, thrust a knife into herself in sight of her kinsfolk, that she might obtain glory for her chastity.] (4.4, [author's own translation])

In the next paragraph, Tertullian (Ad Martyras) refers to the philosophers (Heraclitus, Empedocles and the recent example of Peregrinus) who all died through fire, and then continues to list two women who also despised fire, namely Dido and the wife of Hasdrubal:

[5] Dido, ne post virum dilectissimum nubere cogeretur; item Asdrubalis uxor, quae iam ardente Carthagine, ne maritum suum supplicem Scipionis videret, cum filiis suis in incendium patriae devolavit. [Dido, that she might not be compelled to marry after [the loss of] a most beloved husband: the wife of Asdrubal too, who, while Carthage was now burning, so as not to see her own husband a suppliant before Scipio, rushed with her children into the flames of her native city]. (4.5, [author's own translation])

Next on Tertullian's list (Ad Martyras) is Cleopatra who died from a snakebite:

[6] Bestias femina libens appetiit, et utique aspides, serpentes tauro vel urso horridiores, quas Cleopatra immisit sibi, ne in manus inimici perveniret. [A woman has of her own will taken hold of beasts, yes even asps, reptiles more horrid than the bull or the bear. Cleopatra put these on herself so that she might not fall into the hands of the enemy.] (4.6, [author's own translation])

The last example in Ad Martyras held up as an example to Christian women who are about to die, was that of Leaena:

[7] Sed mortis metus non tantus est, quantus est tormentorum. Itaque cessit carnifici meretrix Atheniensis? Quae conscia coniurationis cum propterea torqueretur a tyranno, et non prodidit coniuratos et novissime linguam suam comestam in faciem tyranni exspuit, ut nihil agere in se sciret tormenta, etsi ultra perseverarent. [But the fear of death is not so great as [the fear] of tortures! And so did the Athenian harlot yield to the executioner? She, who was tortured by the tyrant since she knew of the conspiracy, did not betray the conspirators, and in the end having bitten off her tongue she spat it in the tyrant's face, so that he might know that torture did nothing to her, even though they might have carried on even further.] (4.7, [author's own translation])

The most noticeable aspect of the women Tertullian chose is that, with the exception of Lucretia (who is an example taken from monarchial Rome), these women were not of 
Roman descent and two of them were indeed Carthaginian. ${ }^{11}$ Tertullian is encouraging the Christian women to be brave whilst facing the all-powerful Romans who are about to kill them. To use Roman examples of courage would therefore be psychologically demoralising. Referring to examples of foreign women, whose countrymen also suffered at the hands of the Romans during the expansion of Roman power, was thus a deliberate choice. It is also no coincidence that two Carthaginian women (Dido and Hasdrubal's wife) enjoy pride of place in the list. The Christian women were incarcerated in a Carthaginian jail and their spiritual leader, Tertullian, was born and bred in Carthage. It would be natural for them to identify with Carthaginian exempla.

Each of these women's deaths corresponds with the kind of suffering Christians endured when dying for their faith. Lucretia died by the sword, Dido and the wife of Hasdrubal by fire, snakes killed Cleopatra and Leaena was tortured (Lord 1969:38). Tertullian craftily adapts Cleopatra's death from snakebite to serve as an example of death in the arena. The snakes that bit Cleopatra are more terrible (horridiores) than the bulls and bears of the arena, and therefore snakes are equal to and even worse than wild animals (bestias). With the addition of an explanatory note, Cleopatra thus becomes the example of a woman who was killed by wild animals such as those that devoured the Christians in the arena. The way in which Leaena died also has specific significance in the context, since Tertullian was well aware that the fear of torture was uppermost in the minds of the Christian women he was addressing. It was a fear more difficult to overcome than the fear of death (sed mortis metus non tantus est, quantus est tormentorum) and, just as in the case of Leaena, the refusal to use their tongues to betray their Christianity would lead to death by torture.

There is another dimension to Tertullian's encouragement by example. Not only did these pagan women display courage in the face of death, but their cause was less worthy than that of the Christian women. The women in the examples died for the sake of personal honour (Lucretia), chastity (Dido), patriotism (the wife of Hasdrubal), pride (Cleopatra) and loyalty to earthlings (Leaena), whereas Tertullian was urging his readers to display fortitude in the face of death in order to obtain eternal, celestial glory.

Whilst Tertullian portrays Lucretia and the two Carthaginian women as honourable, Cleopatra and Leaena were women with less savoury reputations. In the Ad Nationes (1.18) Leaena is not identified as a harlot, but here it serves Tertullian's ironic purpose to stress the fact that, in contrast to the Christian women, her lifestyle was anything but blameless. Tertullian includes these examples of degenerate women in his list of examples for the sake of ironic contrast.

\section{To defend the Christians}

Tertullian's foremost work, the Liber Apologeticus, is addressed to the provincial governors of the Roman Empire. According

11.See also Wilhite (2007:66), who refers to Dido and the wife of Hasdrubal as 'two of the greatest examples of anti-Romanism available to his audience'. to Dunn (2002), ${ }^{12}$ the purpose of this work was 'the cessation of persecution'. In chapter 50 he asks the oppressors why they disapprove of the bravery of Christians whilst they applaud the fortitude of others. He then proceeds to name pagan examples of valour. Dido, who gave herself to the fire to avoid a second marriage, is described as a monument of chastity (praeconium castitatis). After mentioning many other male examples, he also refers to the harlot of Athens (Attica meretrix), who bit off and spat her tongue in the face of the raging tyrant in order to also spit out her voice and thus be unable to betray the conspirators.

The choice of these two women from the rhetorical list is deliberate. Two examples of fortitude from opposite ends of Tertullian's morality scale are both acceptable to the Romans. There is some hidden irony here: Dido's morals were beyond reproach in the historical version that Tertullian chose, but she was certainly not seen as such by the Romans. Historically, Carthage had always been a sworn enemy of the Romans, and neither Virgil nor Ovid portrays her as an example of morality with which Christians could identify. Tertullian's loyalty, however, lay with Carthage and her founder, Dido, whom he calls a monument of chastity. He knew that the Romans did not share his admiration and were more familiar with a less flattering version of her courageous death. The other example he found in the pagan category of fortitude was that of an Athenian meretrix, whose morals neither Tertullian nor the Romans could have approved of. The Romans were willing to praise the example of bravery set by a Carthaginian woman (Dido) for whom they had little sympathy and for the most degenerate of women, an Athenian harlot - yet they disapproved of the endurance of Christians!

One of the charges against the Christians was their obstinatio or praesumptio (Tert. Ad Nat. 1.17.1). In chapter 17 of his $A d$ Nationes, Tertullian is bent on defending the persistence of the Christians in their refusal to appease the images of the Caesars and to swear by their genii. The crux of Tertullian's argument is found in the first two paragraphs of the next chapter (chapter 18): The Romans base their charge of obstinacy on the fact that the Christians do not resist their swords, crosses, beasts, fire or tortures (neque gladios neque cruces neque bestias vestras, non ignem, non tormenta [...] recusemus; Tert. Ad Nat. 1.18.1). However, the Romans praise the obstinacy of pagan women who fearlessly faced such trials. Since an eagerness for martyrdom was characteristic of the North African Christians (Dunn 2004:15), Tertullian does not deny the charge of obstinatio [stubbornness]. His first example of martyrdom from the pagan past is that of Cleopatra, queen of Egypt (regina Aegypti), who used her own wild animals (bestias). Tertullian does not explicitly refer to an asp or a snake, but he uses the word bestias in the plural instead of the singular. Using the plural instead of the singular may be an indication that he was influenced by the accounts of Virgil, Florus, Propertius and Horace, who seem to support a 'two-snake theory.' However, in all the ancient

12.As quoted by Wilhite (2007:68) 
accounts of her death, not a single source uses the word bestias. Serpens, ${ }^{13}$ aspis,$^{14}$ viper ${ }^{15}$ and even anguis $^{16}$ are used, but never bestias.

Again Tertullian is deliberately using examples of pagans who faced the same kind of torment as the Christians. He showed that Regulus voluntarily went back to Carthage to be 'crucified'. Following this account of his crucifixion, he needs non-Christian literature to provide an example of somebody who was willingly killed by wild animals (bestias). Just as in Ad Martyras (4), Cleopatra's death is adapted to provide an example of a death similar to that of the Christians who were thrown into the arena with wild animals. Tertullian again equates snakes with wild animals. The word found in ancient literature (and most probably in the list of exempla that Tertullian had at his disposal) is replaced by another for the sake of his argument.

The two Carthaginian women, Dido and the wife of Hasdrubal, again supply the example of death by fire - Dido taught Hasdrubal's wife to be braver than her husband and seek death by fire during Carthage's final hour. Tertullian consistently opts for the earlier account of Dido's death in the Ad Martyras, the Apologeticus, the De Monogamia and the De exhortatione Castitatis, whereas Augustine (Confess. 1.13.20), the only Christian writer to do so, stuck to the Virgilian account, according to which Dido killed herself after being forsaken by Aeneas.

Hasdrubal's wife and her children are also mentioned in Book 2 of the Ad Nationes. Here Tertullian (Ad Nat. 2.9.12-14) employs her fortitude as an example of a person who did not leave her children behind to fall in the hands of the enemy in sharp contrast to the example of Aeneas, who only saved his son and father and left the rest of the Trojans behind. In the first book of Ad Nationes, Tertullian does not mention the children. This omission is deliberate. One of the charges against the Christians, which he adamantly refutes, is the fact that the Christians would kill infants (Tert. Apol. 7.1; Ad Nat. 1.15.1). In using Hasdrubal's wife as an example of fortitude in the Ad Nationes 1, he did not want to augment or enhance the idea that he, as a Christian leader, would seemingly be commending the killing of children. In the Ad Martyras, this detail is not important since he is addressing the Christian martyrs themselves and there is no need to defend their reputation.

In his last example of pagans displaying obstinatio even when facing torture (Ad Nat. 1.18), Tertullian again chooses a woman. He identifies her as the woman of Athens or the Athenian courtesan. Tertullian refers to this 'Athenian woman' in his Ad Nationes, but calls her an 'Athenian courtesan' in the Apologeticus (50) and Ad Martyras (4.7). He never mentions her

13.Florus 2.11; Hor. Carm. 1.37; Vel. Pat. 2.87.

14.Plut. Ant. 86; Strab.17.1.10.

15.Mart. Ep. 4.59

16.Verg. Aen. 8.671-728. by name, but from other non-Christian sources (Plut. Mor. De garr. 505 D-F; Paus. 1.23.2; Ath. 13.596 E-F) we know that her name was Leaena. Unlike his previous examples, Tertullian supplies detail of the historical example she set. In fact, he is the only one of our extant sources to tell us that she bit off her tongue, though it is implied in other sources (Plut. Mor. De garr. 505 D-F). He does not change, add or leave out any 'facts'. Tertullian's point here is that Leaena's stubbornness whilst being tortured equalled and even exceeded that of Christian martyrs. Whilst a simple allusion was enough to remind his pagan audience of Cleopatra's obstinacy, he spells out the details of Leaena's death, which were perhaps less well-known. The Christians who refused to betray their faith by professing (with their tongues) their loyalty to the Caesars, displayed as much obstinatio as the Athenian woman who thwarted the king's efforts to force her to speak by biting off and spitting out her tongue. With this example, Tertullian fully exploits the symbolism of the tongue as an instrument of betrayal.

\section{Pagan exempla of monogamy}

Tertullian's views on marriage were extremely strict and even led to a charge of heresy against him (Lord 1969:27). In his De Monogamia 17, he admonishes Christians who want to marry for a second time, using examples from the history of the church, and also from pagan literature. Christians who want to remarry are put to shame by the pagans and their fidelity to one man. Lucretia provides a ready example in Tertullian's endeavour to inculcate the virtues of chastity, conjugal fidelity and monogamy.

In his De exhortatione castitatis [a letter to a friend who had recently lost his wife], Tertullian praises the pagans for their devotion to monogamy. ${ }^{17}$ He (Tert. De exhortatione castitatis) strongly advises against remarriage and then adds:

Erunt nobis in testimonium et feminae quaedam saeculares ob univiratus obstinationem famam consecutae. [Also certain heathen women who have won fame on account of their persistence in singlehusbandhood will serve as testimony for us.] (13.1, author's own translation)

Here both Dido and Lucretia serve as examples. Lucretia endured another man and, although it happened only onceby force and against her will, she washed her stained flesh in her own blood to avoid living as one who, in her own view, was no longer single-husbanded (ne viveret iam non sibi univira). It is evident why Tertullian again prefers the historical version of a faithful Dido as an example of chastity and fortitude to that of Ovid and Virgil, who portray Dido as more than willing to get married for a second time (Lord 1969:44).

\section{Conclusion}

A close reading of the texts in which Tertullian refers to the exempla of pagan women, reveals that he shifts the examples

17.The same material is used in his Ad Uxorem 1.5. 
from one rubric or virtue to another to suit the context and rhetorical purpose. Dido, the wife of Hasdrubal and Lucretia serve as examples of courage in the face of death, but also fall into the category of conjugal fidelity or Christian monogamy. ${ }^{18}$

Tertullian also manipulates the rhetorical examples at his disposal to fit his purpose. He selects, omits, changes and adapts the well-known examples to substantiate his argument. This adaptation was quite permissible within a rhetorical framework. Quintilian taught:

Potentissimum autem est inter ea quae sunt huius generis, quod proprie vocamus exemplum, id est rei gestae aut ut gestae utilis ad persuadendum id quod intenderis commemoratio. intuendum igitur est, totum simile sit an ex parte, ut automnia ex eo sumamus aut quae utilia sunt. [However, amongst those [arguments] which are of this kind [i.e. relating to proof], the one that we properly call the example is the most powerful, i.e. the remembrance of history or of a useable deed in order to persuade [the hearer] to that which you intend. We must consider, therefore, whether such fact is completely similar to what we wish to illustrate, or only partly so, that we may either adopt the whole of it or only such portion as may serve our purpose.] (Inst. 5.11.6, [author's own translation])

Another determining factor in Tertullian's selection of detail to prove a point is his regard for the addressees. In $\mathrm{Ad}$ Martyras (4), he uses the example of Hasdrubal's wife and relates how she rushed into the flames of burning Carthage with her two sons, so that she would not see her husband as a suppliant to Scipio. His argument (that even pagan woman did not spare their own lives or that of their children to prove their loyalty to a cause) is strengthened by the inclusion of the detail concerning the two boys who died with their mother. However, in his defence of Christian obstinacy (Ad Nat. 1.18) addressed to Roman governors, he cites the same example without mentioning the children so as not to strengthen the suspicion that Christians sacrificed children.

It was also clear from the analysis that Tertullian consistently used the older version of Dido's death that fit in with the Christian doctrine. The martyrs in Carthage could relate to her example of bravery since she was also chaste and modest. By opting for the older version of Dido's example, Tertullian was also able to portray her as a perfect example of devotion to monogamy.

Tertullian consistently applied the rhetorical precepts that his excellent education had provided. His utilisation of examples shows close correlation to Quintilian's standard instructions, but Tertullian adapted the pagan examples to give a new

18.Lord (1969:37) provides lists of these categories. meaning to themes that had become stereotyped in the schools of rhetoric (Carlson 1948:104) as well as in Roman literature. The Romans were well acquainted with Tertullian's examples, but not with the Christian context within which he employed them. By supporting his Christian argument with pagan examples, Tertullian was using a rhetorical tool familiar to the Romans to introduce a doctrine that they viewed with suspicion. The reworked and adapted examples of pagan women in Tertullian's work illustrate how and why ancient rhetoric became part of Christian literary tradition.

\section{Acknowledgements Competing interests}

The authors declare that they have no financial or personal relationship(s) that may have inappropriately influenced them in writing this article.

\section{Authors' contributions}

Both authors (North-West University) equally contributed to the research and writing of this article.

\section{References}

Barnes, T.D., 1971, Tertullian: A historical and literary study, Clarendon Press, Oxford. Carlson, M.L., 1948, 'Pagan examples of fortitude in the Latin Christian apologists', Classical Philology 43(2), 93-104. http://dx.doi.org/10.1086/363088

Cary, M. \& Scullard, H.H., 1994, A history of Rome down to the reign of Constantine, The Macmillan Press, London.

Clark, G., 2004, Christianity and Roman society, Cambridge University Press, Cambridge. http://dx.doi.org/10.1017/CBO9780511803536

Daniel-Hughes, C., 2011, The salvation of the flesh in Tertullian of Carthage, Palgrave Macmillan, New York. http://dx.doi.org/10.1057/9780230338074

D’Arms, J.H., 1972, 'Pro Murena 16 and Cicero's use of historical exempla', Phoenix 26(1), 82-84. http://dx.doi.org/10.2307/1087211

De Ste. Croix, G.E.M., 1963, 'Why were the Christians persecuted?', Past and Present 26, 6-38. http://dx.doi.org/10.1093/past/26.1.6

Dunn, G.D., 2002, 'Rhetorical structure in Tertullian's Ad Scapulam', Vigiliae Christianae 56, 47-55. http://dx.doi.org/10.1163/15700720252984828

Dunn, G.D., 2004, Tertullian, Routledge, New York.

Edgeworth, R.J., 1977, 'The death of Dido', The Classical Journal 72(2), 129-133.

Lord, M.L., 1969, 'Dido as an example of chastity: The influence of example literature', Harvard Library Bulletin 17(1), 22-44.

Norris, R., 2004, The Apologists: The Cambridge history of early Christian literature, Cambridge University Press, Cambridge.

Osborn, E., 1997, The first theologian of the west, Cambridge University Press, Cambridge.

Sider, R.D., 1971, Ancient rhetoric and the art of Tertullian (Oxford theological monographs), Oxford University Press, Oxford.

Sider, R.D., 1974, 'Timothy David Barnes. Tertullian. A historical and literary study (Review)', American Journal of Philology 95, 302-303. http://dx.doi. org/10.2307/293923

Ueding, G., 1996, Rhetorik des Schreibens, Eine Einführung, Athenäum, Landsberg.

Wedderburn, A.J.M., 2004, A history of the first Christians, T\&T Clark, London.

Wilhite, D.E., 2007, 'Tertullian the African: An anthropological reading of Tertullian's context and identities', Millennium Studies, vol. 14, Walter de Gruyter, Berlin. http://dx.doi.org/10.1515/9783110926262

Woodham, H.A., 1848, Q. Septimii Tertulliani liber Apologeticus, Cambridge University Press, Cambridge. 